\title{
CZY STANDARYZACJA CSR SPRZYJA ODPOWIEDZIALNOŚCI BIZNESU?
}

\section{WSTĘP}

Niezwykle wpływowa i rozpowszechniona koncepcja społecznej odpowiedzialności biznesu (corporate social responsibility - CSR) wdrażana na wielu poziomach instytucjonalnych i różnych obszarach stanowi swoistą podstawę doktrynalną współczesnych działań gospodarczych. Chociaż zwolennicy i propagatorzy CSR przyjmują jej słuszność za niepodlegające dyskusji założenie, warto pamiętać, że teoretyczny spór dotyczący samej istoty tej koncepcji nie został definitywnie rozstrzygnięty, a argumenty za i przeciw sa poddawane teoretycznej analizie. Jednak firmy deklarujące społeczną odpowiedzialność, a także organizacje i instytucje ja promujące pomijają milczeniem ów spór i kierują swoją uwagę i wysiłek na sposoby realizacji postulatów CSR. Zawieszając refleksję nad teoretycznymi kontrowersjami wokół CSR, którą podejmowałam w swoich publikacjach ${ }^{1}$, zamierzam $\mathrm{w}$ artykule skierować uwagę na zagadnienia związane ze standaryzacją tej koncepcji i zastanowić się, czy i w jakim stopniu owa standaryzacja służy celom, do jakich jest tworzona.

Standaryzacja CSR przejawia się w budowaniu i wykorzystywaniu instrumentów, z jednej strony mających pomagać firmom w urzeczywistnianiu tej idei w praktyce, a z drugiej - umożliwiać zewnętrzną ocenę i kontrolę biznesu pod względem wywiązywania się z obowiązków wobec społeczeństwa. Owe instrumenty przybierające zróżnicowane formy kodeksów, wytycznych, norm, raportów, systemów audytu czy komunikowania prospołecznych działań firmy tworza, obecnie bardzo rozbudowana, rodzinę standardów CSR. Najbardziej znane wśród nich to: UN Global Compact, ISO 26000, AA1000, SA8000, Global Reporting Initiative (GRI). Standardy dzięki adaptowaniu odpowiednich wskaźników i ich agregacji maja pozwolić na obiektywizację ocen społecznego i ekologicznego wymiaru funkcjonowania firmy i ich porównywalność, podobną do tej, jaką stwarzają wskaźniki finansowe czy ekonomiczne. Inaczej mówiąc, pytanie o „wynik społeczny” firmy za dany rok powinno być równie sensowne, jak pytanie o jej dochód.

Jednak standaryzacja polimorficznej, rozmytej i niejednoznacznie interpretowanej idei zarządzania odpowiedzialnością społeczną napotyka na utrudnienia zarówno merytorycznej, jak i formalnej czy technicznej natury. Efektem

1 A. Lewicka-Strzałecka, Etyczne standardy firm i pracowników, IFiS PAN, Warszawa 1999; eadem, Odpowiedzialność moralna w życiu gospodarczym, IFiS PAN, Warszawa 2006. 
tych utrudnień jest coraz częściej sygnalizowane pozorowanie urzeczywistniania CSR przez firmy, polegajace na fasadowym wprowadzeniu infrastruktury CSR, któremu towarzyszy oderwanie (decoupling) zasad CSR od praktyki działań organizacji ${ }^{2}$. Tymczasem entuzjaści CSR nie tylko zapominają o teoretycznych zastrzeżeniach wobec tej koncepcji, ale promując poszczególne standardy, na ogół nie wspominają o ich ograniczeniach. Identyfikacja tych ograniczeń i ich krytyczna analiza ma na celu przybliżenie do odpowiedzi na tytułowe pytanie o rolę standaryzacji w kształtowaniu społecznej odpowiedzialności biznesu.

Artykuł ma następująca strukturę. Rozpoczyna się od rekonstrukcji celów i form standaryzacji CSR, następnie przedstawia spektrum standardów CSR, pokazując możliwe ich uporządkowania. Kolejna część artykułu sięga do danych empirycznych weryfikujących efektywność standardów CSR, w części ostatniej zaś podejmuję analizę przyczyn zawodności tych standardów.

\section{CELE, FORMY I STATUS STANDARYZACJI CSR}

Standaryzacja CSR ma na celu wdrożenie idei społecznej odpowiedzialności do praktyki działania firm, a także umożliwienie kontroli realizacji tego przedsięwzięcia. Wiąże się to z opracowywaniem narzędzi, za pomocą których abstrakcyjne pojęcia, wartości i ogólne reguły zostaną przekształcone w konkretne sposoby działania, możliwe do monitorowania i oceniania rezultaty tych działań. Standaryzacja CSR powinna sprzyjać upowszechnieniu tej idei, ponieważ rutynizacja pewnych procesów i praktyk ułatwia ich przenikanie do różnych obszarów. Ich wykorzystywanie zmniejsza koszty transakcyjne współpracy organizacji z odmiennych kręgów kulturowych i różnych porządków prawnych. Posługiwanie się podobnymi narzędziami przez różne organizacje umożliwia porównywalność ich społecznej aktywności i eliminowanie nieporozumień pojęciowych.

Standaryzacja ma szczególne znaczenie w odniesieniu do międzynarodowych korporacji, których działania wymykają się często regulacjom prawnym i ograniczeniom stawianym przez państwa narodowe. Jej celem jest „pobudzanie i ukierunkowanie odpowiedzialności przedsiębiorstw i dostarczanie międzynarodowym korporacjom instrumentów do oceny, pomiaru i komunikowania ich społecznych i środowiskowych dokonań”3. Międzynarodowe standardy CSR opracowywane przez niezależne instytucje są skierowane na monitorowanie działań organizacji, których obroty przekraczają PKB niektórych państw. Znaczenie tych standardów będzie rosło wraz z postępującymi procesami globalizacyjnymi ${ }^{4}$, ponieważ stwarzają szansę na zewnętrzną kontrolę

${ }^{2}$ M. Behnam, T. L. MacLean, Where is the accountability in international accountability standards? A decoupling perspective, „Business Ethics Quarterly” 21(1), 2011, s. 45-72.

${ }^{3}$ D. U. Gilbert, A. Rasche, S. Waddock, Accountability in a global economy: the emergence of international accountability standards, „Business Ethics Quarterly”21(1), 2011, s. 23.

${ }_{4}^{4}$ T. Beschomer, M. Müller, Social standards: toward an active ethical involvement of businesses in developing countries, „Journal of Business Ethics” 73(1), 2007, s. 11-20; G. Gereffi, R. Garcia-Johnson, E. Sasser, The NGO-industrial complex, „Foreign Policy” 125, 2001, s. 56-65. 
gigantów i pohamowanie ich destrukcyjnych dla społeczeństwa i środowiska działań, i tym samym wprowadzają dodatkowe reguły gry w światowej gospodarce. Wypełniaja one lukę między intensywnym rozwijaniem globalnych rynków, np. w postaci restrykcyjnego prawa do własności intelektualnej a słaba ochroną praw pracowniczych, w szczególności zakazu zatrudniania dzieci czy pracy przymusowej.

Tworzenie i wdrażanie standardów CSR angażuje na ogół różne grupy interesariuszy, dzięki czemu możliwe jest ich wzajemne poznanie i współpraca, a przede wszystkim wkład $\mathrm{w}$ doskonalenie zarządzania CSR danej organizacji. Taki proces powinien mieć ciagły charakter, uwzględniający zmiany zachodzace w różnych sferach gospodarki. Granica między standardami CSR a etycznymi zasadami postępowania firmy znajdujacymi się na ogół w jej kodeksie, które dla uproszczenia nazwijmy standardami etycznymi nie jest łatwa do wytyczenia. Niektórzy badacze uważaja ${ }^{5}$, że polega ona na tym, że standardy CSR, które przyjmuje firma, są formułowane na zewnatrz, natomiast standardy etyczne są efektem jej własnego wysiłku. Na ogół tak jest, ale warto pamiętać, że pierwsza i modelowa deklaracja społecznej odpowiedzialności, czyli Credo firmy Johnson \& Johnson powstała w 1941 r. wewnątrz firmy, w wyniku inicjatywy menedżerów nią zarządzających. Warto również podkreślić, że w sytuacji próby (w 1972 r.), czyli kryzysu związanego z wprowadzeniem na rynek tylenolu, który spowodował śmierć kilku osób, menedżerowie postawili na pierwszym miejscu zdrowie i bezpieczeństwo ludzi, kosztem ogromnych strat finansowych. Wykazali w autentyczny sposób społeczna odpowiedzialność, pomimo braku formalnych standardów CSR.

Standardy etyczne firmy i standardy CSR są ze sobą ściśle powiązane. Kodeksy etyczne firm mają często strukturę opartą na katalogowaniu zobowiązań wobec poszczególnych grup interesariuszy, czyli standardach CSR. Z kolei standardy CSR na przykład wytyczne raportowania GRI postulują ujawnienie wartości, zasad, standardów i norm organizacji, jej wewnętrznych i zewnętrznych mechanizmów konsultacji w zakresie etycznego i zgodnego z prawem zachowania, a także mechanizmów zgłaszania przypadków nieetycznego lub bezprawnego zachowania, czyli etyczne działania są traktowane jako standardy CSR.

Być może istotną różnicą między rozważanymi rodzajami standardów jest to, że standardy etyczne sa pewnymi wzorami normującymi zachowania jednostek, natomiast standardy CSR mają stanowić modele działań organizacji. Ostatecznie jednak te ostatnie również powinny być wdrażane lub są zaniedbywane przez menedżerów zarządzających organizacjami.

Dobrowolnie przyjmowane standardy CSR sa rodzajem miękkiego prawa regulującego funkcjonowanie firm. Standardy CSR są mniej precyzyjne niż zapisy tzw. twardego prawa i nie przewiduje się formalnych sankcji za ich naruszenie. Jednak z czasem niektóre z nich podlegaja „utwardzeniu” i zostają przekształcone w oficjalne regulacje, np. standardy środowiskowe ISO

${ }^{5}$ A. Rasche, Toward a model to compare and analyze accountability standards: the case of the UN Global Compact, „Corporate Social Responsibility and Environmental Management” 16(4), 2009, s. 192-205. 
zostały wykorzystane w państwowych rozporządzeniach, a przygotowanie społecznych raportów przez wielkie firmy stało się obowiązkowe na mocy unijnej dyrektywy. Przyjęcie standardów CSR jest w pewnych sektorach warunkiem wstępnym nawiązania relacji biznesowych. Znane marki np. w branży odzieżowej wymagają od swoich kontrahentów certyfikatów zaświadczających przestrzeganie przez nich praw pracowniczych. Standardy CSR są również przyjmowane pod presją wywierana przez organizacje pozarządowe, stowarzyszenia konsumenckie oraz związki zawodowe.

\section{KATEGORYZACJE I MAPA STANDARDÓW CSR}

Wywierana z wielu stron presja na firmy, by podejmowały i legitymowały się społeczną odpowiedzialnością skutkuje tworzeniem narzędzi umożliwiających realizację tych zadań. Liczba standardów CSR jest tak duża, że tworzone są typologie mające ułatwiać orientowanie się w tej mnogości wytycznych i wskaźników. Na przykład ${ }^{6}$ wyróżnia się standardy zorientowane na wynik (np. unikanie pracy dzieci) i na proces (np. system zarządzania, który jest tak zaprojektowany, by uniknąć pracy dzieci). Andreas Rasche i Daniel Esser ${ }^{7}$ proponują kategoryzację opartą na następujących kryteriach, ze względu na które można analizować i porównywać standardy: 1) natura (wynik, certyfikacja, proces), 2) obszar zastosowania (społeczne, ekonomiczne, ekologiczne), 3) koncentracja (na rozliczeniu, audytowaniu, raportowaniu) 4) zasięg geograficzny (globalny, regionalny, lokalny) 5) poziom (ogólny, branżowy, przedsiębiorstwa). Dirk Gilbert and Andreas Rasche ${ }^{8}$ porządkują standardy CSR ze względu na trzy podstawowe aspekty: 1) rodzaj kodyfikowanych kwestii (społeczne, ekologiczne lub łaczone), 2) charakter procesu standaryzacji (rozliczeniowy, raportowy, ubezpieczeniowy), 3) poziom szczegółowości norm (ogólne lub szczegółowe instrukcje dla odrębnych sektorów). Ten ostatni poziom jest podstawą do klasyfikacji, zgodnie z którą rozróżnia się standardy zorientowane na jeden aspekt (np. warunki pracy, zanieczyszczenie środowiska) lub jednego interesariusza (np. pracownicy, dostawcy) i ogólne systemy zarządzania obejmujące szerokie spektrum kwestii społecznych i ekologicznych oraz relacje między różnymi interesariuszami ${ }^{9}$.

Analizując rozmaite klasyfikacje i typologie standardów CSR, Simone de Colle $\mathrm{i}$ in. ${ }^{10}$ sporządzili swoistą ich mapę, która została wytyczona przez na-

${ }^{6}$ D. Leipziger, The Corporate Responsibility Code Book, Greenleaf, Sheffield 2003.

${ }^{7}$ A. Rasche, D. E. Esser, From stakeholder management to stakeholder accountability - applying Habermasian discourse ethics to accountability research, „Journal of Business Ethics” 65(3), 2009, s. 251-267.

${ }^{8}$ D. U. Gilbert, A. Rasche, Discourse ethics and social accountability - the ethics of SA 8000 , „Business Ethics Quarterly” 17(2), 2007, s. 187-216; eidem, From stakeholder management to stakeholder engagement, „Journal of Business Ethics” 82(3), 2008, s. 755-773.

${ }^{9}$ S. de Colle, CSR and management systems, w: J. Alluche (ed.), Corporate Social Responsibility. Concepts, Accountability and Reporting, Palgrave MacMillan, New York 2006.

${ }^{10} \mathrm{~S}$. de Colle, A. Henriques, S. Sarasvathy, The paradox of corporate social responsibility standards, „Journal of Business Ethics” 125(2), 2014, s. 177-191. 
stępujące wymiary. Pierwszy wymiar różnicuje standardy ze względu na ich procesualny bądź substancjalny charakter. Standardy procesualne normuja systemy zarządzania, zapewniając pożądany przebieg procesów czy działań istotnych z uwagi na cel zarządzania, jak w przypadku AccountAbility 1000, ustanawiającego etyczne zasady rachunkowości, audytu i raportowania. Standardy substancjalne wytyczają kształt działań w obszarze CSR. Na przykład UN Global Compact obejmuje dziesięć zasad, którymi powinny kierować się wszystkie organizacje, GRI wskazuje obszary, które powinny być uwzględniane w raporcie, SA8000 określa politykę wobec dostawców. Drugi wymiar określa poziom ogólności standardów, dzieląc je na te, które sa nastawione na podejmowanie szerokiej społecznej, etycznej i środowiskowej odpowiedzialności, oraz te, które mają bardziej szczegółowy charakter (np. prawa człowieka) czy powinności wobec wybranych grup interesariuszy (np. konsumentów). Trzeci wymiar został wyznaczony przez proces monitorowania standardów, który w pewnych przypadkach ma postać audytu dokonywanego przez trzecia stronę, w innych ma formę certyfikatu, a w jeszcze innych nie jest w ogóle przewidywany. Ostatni wymiar określa zakres udziału interesariuszy w procesie tworzenia bądź zarządzania standardem.

Próby kategoryzacji standardów CSR podejmowane są również w polskiej literaturze. Na przykład Łukasz Makuch ${ }^{11}$ wyróżnia następujące ich grupy: 1) aspiracyjne zasady i kodeksy postępowania, 2) wytyczne odnośnie do systemu zarządzania oraz systemy certyfikacji, 3) wskaźniki oceny używane przez agencje inwestycyjne, 4) wytyczne raportowania i komunikacji.

Szczególne miejsce wśród standardów CSR zajmują raporty, w których firmy przedstawiają informacje o swojej działalności, wykraczające poza wymagane przez prawo standardowe czy finansowe dane. Raporty te określane jako raporty zrównoważonego rozwoju, społecznej odpowiedzialności, a najkrócej: raporty społeczne - prezentuja dokonania i zamierzenia firmy w trzech wymiarach: ekonomicznym, środowiskowym i społecznym. Przygotowują je głównie wielkie firmy; z badania KPMG wynika, że $92 \%$ spośród 250 największych międzynarodowych korporacji opracowuje raporty zgodnie z metodologią GRI (KPMG 2105). Raporty społeczne są instrumentem komunikowania się firmy z otoczeniem, z poszczególnymi interesariuszami, służą usprawnieniu zarządzania CSR w firmie, a także umożliwiają zewnętrzną ocenę i kontrolę biznesu pod względem wywiązywania się z obowiązków wobec społeczeństwa.

Ten ostatni wzgląd stał się podstawą do sformułowania unijnej dyrektywy (2014/95/UE z 22 października 2014 r.) nakładającej na niektóre jednostki obowiązek raportowania danych niefinansowych. Postanowienia tej dyrektywy będą w naszym kraju realizowane zgodnie ze znowelizowaną ustawę o rachunkowości, która weszła w życie 1 stycznia 2017 r. Obowiązkiem pozafinansowego raportowania objęte zostały firmy, których średnioroczne zatrudnienie wynosi minimum 500 osób oraz suma aktywów bilansu przekracza 85 milionów złotych lub suma przychodów netto ze sprzedaży towarów i produktów przekracza 170 milionów złotych. Szacuje się, że takich firm jest w Polsce około 300. Zgodnie

11 Ł. Makuch, Normy i standardy społecznej odpowiedzialności biznesu (CSR), 2011, https:// obszarcsr.files.wordpress.com/2011/04/standardy_csr.pdf [dostęp: 15.06.2017]. 
z nowymi wymaganiami odpowiednie jednostki będą zobowiązane ujawnić swój model biznesowy, kluczowe niefinansowe wskaźniki efektywności zwiąane z działalnością jednostki oraz politykę jednostki w odniesieniu do zagadnień społecznych, pracowniczych, środowiska naturalnego, poszanowania praw człowieka, przeciwdziałania korupcji i łapownictwu, a także rezultaty jej stosowania. Jeżeli dana jednostka nie prowadzi polityki w odniesieniu do tych zagadnień, powinna ujawnić ten fakt wraz z podaniem przyczyn, zgodnie z zasada „stosuj lub wyjaśnij”. Ponadto powinny zostać ujawnione istotne rodzaje ryzyka związane z działalnością jednostki, w szczególności ryzyko związane z produktami jednostki lub jej relacjami z otoczeniem zewnętrznym, a także opis zarządzania tym ryzykiem. Biegły rewident musi potwierdzić, czy oświadczenie lub sprawozdanie zostało sporządzone, natomiast informacje pozafinansowe w postaci oświadczenia lub sprawozdania nie będą podlegały obowiązkowi audytu.

\section{EFEKTYWNOŚĆ STANDARDÓW CSR W ŚWIETLE DANYCH EMPIRYCZNYCH}

Praktyka funkcjonowania standardów CSR dostarcza całego spektrum odpowiedzi dotyczących kwestii ich efektywności. Można odwołać się do spektakularnych przykładów świadczących o ich całkowitej zawodności, pewne dane ilustrują neutralne znaczenie standardów, a jeszcze inne wskazują na zwiększenie społecznej odpowiedzialności firm objętych standardami. Te pierwsze przykłady przekonująco ilustrują poniższe przypadki, które wstrząsnęły światową opinią publiczna.

Pierwszy przypadek dotyczy firmy British Petroleum (BP) cieszaccego się reputacja najbardziej odpowiedzialnego na świecie koncernu wydobywającego gaz i ropę ${ }^{12}$. Firma ta ogłasza regularnie coroczny raport zrównoważonego rozwoju. Majacy w tytule słowo bezpieczeństwo (safety) Raport BP za rok 2009 został opublikowany 15 kwietnia 2010 r. Było to na pięć dni przed katastrofa ekologiczną w Zatoce Meksykańskiej spowodowaną eksplozją platformy wiertniczej Deepwater Horizon. Eksplozja zapoczątkowała gigantyczny wyciek ropy, którego wielkość szacowana jest na 5 mln baryłek, a katastrofa uważana jest za największą katastrofę ekologiczną w dotychczasowej historii USA. Zgodnie z praktykowanymi w sferze CSR standardami raport BP zawierał trzy części: ekonomiczna, ekologiczną i społeczną i jego poprawność została potwierdzona przez znaną firmę audytorską Ernst \& Young. Szczegółowa analiza raportu wskazuje, że można w nim było znaleźć pewne oznaki niepokoju o bezpieczeństwo wyrażone przez niezależnego eksperta oraz zalecenia poprawy pewnych procedur artykułowane przez ubezpieczyciela. Jednakże ogólny ton raportu był zdominowany przez CSR-owski żargon zapewniający, że firma czyni zrównoważony rozwój swoją najwyższą wartościa, zalewający pustymi określeniami i górnolotnymi deklaracjami, niepozwalający na dostrzeżenie i zrozumienie operacyjnego ryzyka związanego z działaniami BP w Zatoce Meksykańskiej.

${ }^{12}$ Zob. https://en.wikipedia.org/wiki/Deepwater_Horizon_oil_spill [dostęp: 10.05.2017]. 
Raport rozpoczyna się od deklaracji, że BP nieustannie doskonali swoje standardy bezpieczeństwa przez procedury, procesy i programy szkoleniowe, które wdraża, dążąc do celu określonego jako całkowite wyeliminowanie wypadków, szkód ludzkiego zdrowia i niszczenia środowiska. Prezes firmy Tony Harward wyraża dumę z wysokiego poziomu bezpieczeństwa, który firmie udało się osiagnać w podsumowywanym roku i który jest efektem systematycznego wysiłku wkładanego w każde działanie w ciagu wielu lat. Przez cały raport przewija się słowo bezpieczeństwo w konfiguracji ze wszystkimi działaniami firmy. Jak zauważa Janet Mobus ${ }^{13}$, niezbyt kategoryczne, ale istotne ostrzeżenia zginęły w morzu zapewnień BP o nieustannym doskonaleniu się, rozmywających transparentność i uniemożliwiających zauważenie potencjalnego ryzyka.

Drugi przypadek ilustrujący zawodność standardów CSR, przejawiająca się także w postaci braku wiarygodności społecznych raportów, dotyczy ujawnionego we wrześniu 2015 r. procederu montowania w samochodach produkowanych przez koncern Volkswagen oprogramowania pozwalajacego na manipulację wynikami pomiarów emisji spalin z układu wydechowego. Zwodnicze oprogramowanie zostało zainstalowane w 11 milionach samochodów, koszty, jakie musiał ponieść koncern na skutek tego oszustwa, szacuje się na ponad 20 miliardów dolarów. W raportach zrównoważonego rozwoju, w szczególności raporcie za rok 2014, audytowanym przez PricewaterhouseCoopers, Volkswagen deklaruje swoją troskę o klienta, pracowników, a także o środowisko naturalne. Środowisko naturalne zostało w raporcie wymienione 335 razy na 156 stronach, przeciętnie dwukrotnie na każdej. Firma odwołuje się do długiej tradycji troski o środowisko naturalne oraz zapewnia, że całą swoją inwencję skieruje na pożytek ludzi i przyrody. Zorganizowane oszustwo ukryte w patetycznych zwrotach i uroczystych deklaracjach w istotny sposób przyczyniło się do deprecjacji idei raportów zrównoważonego rozwoju i szerzej - praktyk CSR. Warto w tym kontekście dodać, że działaniom firmy niszczacym środowisko naturalne nie zapobiegł formalny program CSR. System informowania o nadużyciach okazał się nieskuteczny, ponieważ zgłoszenia niektórych techników i inżynierów o nieprawidłowościach zostały zignorowane.

Niewiarygodne okazały się również raporty CSR firmy Wells Fargo, największego amerykańskiego banku hipotecznego, w szczególności raport za rok 2015. Wśród naczelnych zasad banku jego prezes Stumpf wskazał ukierunkowanie na dobro i interes finansowy klientów oraz troskę i wsparcie udzielane pracownikom. Wells Fargo posiada kodeks etyczny, w którym deklaruje najwyższe standardy etyczne, m.in. gotowość służenia klientom i budowania z nimi długotrwałych relacji. Tymczasem w okresie 2011-2014 bank pozakładał swoim klientom, bez ich zgody i wiedzy, 2 miliony fikcyjnych kont i kart kredytowych, by dzięki temu zwiększyć słupki sprzedażowe, co w szybkim czasie przełożyło się na szybujące kursy akcji ${ }^{14}$. Pracownicy dopuszczali się takich praktyk z powodu zbyt wyśrubowanych norm sprzedaży, jakich od nich wymagano i za których realizację byli wynagradzani. Doradcy posuwali się nawet do tworzenia PIN-ów

${ }^{13}$ J. L. Mobus, Corporate social responsibility (CSR) reporting by BP: revealing or obscuring risks?, „Journal of Legal, Ethical and Regulatory Issues” 15(2), 2012, s. 35-52.

14 Zob. http://www.bankier.pl/wiadomosc/Afera-kont-widm-pracownicy-Wells-Fargo-zwolnieni-menedzer- z-olbrzymia-odprawa-7477227.html [dostęp: 10.05.2017]. 
i używali specjalnie otwieranych adresów e-mail do zakładania klientom kont bankowych. Wielu klientów się nie zorientowało, ale część poszkodowanych zaczęło protestować i składać reklamacje. Wtedy pracownicy informowali ich o „błędzie komputerowym” albo innej „pomyłce”. Analitycy branżowi zachęcali do kupowania akcji banku, co jeszcze bardziej pompowało bańkę. Kiedy oszustwo ujrzało światło dzienne, nie zwolniono nikogo z kadry zarządzającej. Zamiast tego podziękowano 5300 szeregowym pracownikom, którzy sporządzali fikcyjne umowy. Chociaż szefowa działu sprzedaży została zmuszona do odejścia, to została wynagrodzona wielomilionowym pakietem akcji banku za realizację celów strategicznych. Prezes również odszedł, zrzekając się części swojego wynagrodzenia za 2016 r. Wells Fargo musi zapłacić karę w wysokości 185 milionów dolarów i 5 milionów tytułem zadośćuczynienia oszukanym klientom. Warto zauważyć, że nadużyciom popełnianym na masową skalę nie zapobiegły ani istniejąca w firmie komórka etyczna i zatrudnieni w niej menedżerowie ds. etyki, ani formalnie funkcjonujaccy system sygnalizowania nadużyć.

Wśród danych empirycznych ilustrujących brak efektywności pewnych szczególnych standardów CSR wskazuje się program „Responsible Care”, do którego dobrowolnie przystępowały firmy chemiczne, zobowiąując się do ograniczenia emisji zanieczyszczeń. Opierając się danych obejmujących funkcjonowanie 1500 firm w ciagu 10 lat, Andrew King i Michael Lenox ${ }^{15}$ wykazali, że sygnatariusze programu wykazywali znacznie mniejszy postęp w ograniczaniu emisji niż firmy, które do programu nie przystapiły. King i Lenox sugeruja, że mogło to być spowodowane trudnością tworzenia samoregulacji bez żadnych sankcji za niedotrzymanie zobowiazzań. Brak pozytywnych efektów przyjęcia CSR standardów w postaci redukcji negatywnego oddziaływania na środowisko wykazała także analiza blisko 8 tysięcy amerykańskich firm, które posiadały certyfikat ISO $14000^{16}$. Przypuszcza się, że spowodowane to było faktem, że o ISO 14000 starały się firmy, które wcześniej poprawiły swoje zarządzanie środowiskowe, a sam certyfikat nie wpływał w żaden sposób na to zarządzanie. Karykaturalnym przykładem deklaracji CSR było przyjęcie przez Shella certyfikatu ISO $14001 \mathrm{w}$ operacji pozyskiwania ropy z piasków bitumicznych w Kanadzie. ISO 14001 jest standardem majacym kierować proces zarządzania na ochronę środowiska, natomiast pozyskiwanie ropy z piasków bitumicznych jest praktyką drastycznie dewastującą środowisko.

Znikome rezultaty przyniosła inicjatywa etycznego handlu (Ethical Trading Inititive), mająca poprawić warunki pracy osobom zatrudnionym w łańcuchu dostaw ${ }^{17}$. Mało efektywna okazała się także inicjatywa SA8000, której przyświecały podobne cele ${ }^{18}$.

${ }^{15}$ A. King, M. Lenox, Industry self-regulation without sanctions: the chemical industry's responsible care program, „Academy of Management Journal” 43, 2000, s. 698-716.

${ }^{16}$ A. King, M. Lenox, A. Terlaak, The strategic use of decentralized institutions: exploring certification with the ISO 14001 management standard, „Academy of Management Journal” 48(6), 2005, s. 1091-1106.

${ }_{17}$ S. Barrientos, S. Smith, The ETI code of practice: do workers really benefit?, IDS, Brighton 2007.

${ }_{18}$ M. J. Hiscox et al., Evaluating the impact of SA 8000 Certification, w: D. Leipziger (ed.), Social Accountability 8000: The First decade Implementation, Influence, and Impact, Greenleaf, Sheffield 2009, s. 147-165. 
Jednak inne przykłady wskazuja na pozytywne efekty wprowadzenia standardów CSR. Na przykład Ann Terlaak i Andrew King ${ }^{19}$ wykazali wzrost przewagi konkurencyjnej firm posiadających standard zarządzania jakościa ISO 9000. Nie udało się co prawda sprawdzić, czy ów standard miał wpływ na poprawę jakości produktów. Prawne i ekonomiczne analizy ujawniły wiele pożądanych skutków upowszechnienia standardów CSR w postaci redukcji kosztów transakcyjnych na różnych poziomach, ograniczenia złożoności zarządzania relacjami firmy z otoczeniem zewnętrznym, obniżenia kosztów monitorowania i kontroli, redukcji kosztów komunikacji wewnątrz łańcucha dosta $^{20}$. Wyniki tych analiz wzmacniają tezę o pozytywnej roli standardów CSR $\mathrm{w}$ postaci kreowania warunków sprzyjajacych prowadzeniu biznesu, szczególnie w tych rejonach świata, gdzie prawo jest słabe.

Majac na uwadze rozważane wyżej relacje między standardami CSR i programami etycznymi firm, warto przywołać wyniki sondażu wskazującego na korzystny wpływ tych ostatnich na zachowania pracowników. Ten amerykański, ogólnokrajowy sondaż, powtarzany cyklicznie od 1994 r., potwierdza pozytywną zależność między kulturą firmy tworzoną przez programy etyczne a niższym odsetkiem obserwowanych nadużyć popełnianych przez pracowników ${ }^{21}$.

\section{PODSUMOWANIE: DLACZEGO STANDARDY CSR CZĘSTO NIE SPEŁNIAJĄ SWOJEJ ROLI, A NAWET BYWAJĄ PRZECIWSKUTECZNE?}

Standardy CSR z natury rzeczy mają być narzędziami umożliwiającymi zarządzanie złożonym fenomenem odpowiedzialności w praktyce funkcjonowania firm. Jednakże zarówno teoretyczna refleksja, jak i stosunkowo długa praktyka funkcjonowania standardów CSR wskazują na istotne ograniczenia tego przedsięwzięcia. Standaryzacja niejednoznacznych i złożonych kwestii społecznych i etycznych okazuje się daleko bardziej skomplikowana niż unifikacja zagadnień technicznych ${ }^{22}$. Podstawowe zasady konstytuujace fenomen odpowiedzialności (np. te, które są zawarte w Global Compact, dotyczące praw człowieka, zachowania różnorodności, przeciwdziałania dyskryminacji, promowania postaw odpowiedzialności ekologicznej), zostały sformułowane na wysokim poziomie ogólności i bazują na rozwiniętych teoretycznych koncepcjach dopuszczających rozmaite interpretacje, które są pogłębiane rozbieżnościami pojęciowymi, czynnikami sytuacyjnymi bądź

19 A. Terlaak, A. King, The effect of certification with the ISO 9000 quality management standard: a signaling approach, „Journal of Economic Behavior \& Organization” 60(4), 2006, s. 579-602.

${ }^{20}$ M. M. Blair, C. A. Williams, L.-W. Lin, The Roles of Standardization, Certification, and Assurance Services in Global Commerce, Paper presented at the conference CSR: Law, Operations, and Strategy, Georgetown University, Washington, D.C., Nov 7, 2008.

${ }^{21}$ National Business Ethics Survey, Ethics Resource Center, 2014.

22 A. Henriques, Corporate Impact: Measuring and Managing your Social Footprint, Earthscan, London 2010. 
zmiennymi kulturowymi. Owa dowolność interpretacji daje poczucie zgodności działań z wysokimi zasadami CSR szerokiemu kręgowi firm zasadniczo różniących się między sobą pod względem wywiązywania się z obowiązków wobec społeczeństwa czy środowiska. Wielość i różnorodność funkcjonujących standardów nie tylko nie usuwa problemów pojęciowych i interpretacyjnych, ale raczej je pogłębia.

Z drugiej strony próba bardziej precyzyjnego uchwycenia poziomu przestrzegania ogólnych zasad za pomoca pojedynczego wskaźnika lub nawet kilku takich wskaźników tylko w niewielkiej części może oddać istotę urzeczywistniania odpowiedzialności i przypomina usiłowania odwzorowania brzmienia orkiestry symfonicznej za pomocą dźwięku jednego instrumentu. Parametryzacja CSR przyjęta choćby w GRI pozostawia niewiele miejsca na swobodna interpretację, ale istotne dla odpowiedzialności kwestie mogą się wymknąć spod kontroli. Wykazanie się przez firmę dużym odsetkiem przeszkolonych pracowników w zakresie polityki poszanowania praw człowieka może iść w parze z niskim poziomem jakości szkoleń, a brak zgłoszeń incydentów o charakterze dyskryminacyjnym nie musi świadczyć o efektywnej polityce antydyskryminacyjnej, ale może być efektem niskiej świadomości pracowników $\mathrm{w}$ tym zakresie czy obawy przed szykanami. Wykazywanie odpowiedzialności firmy za pomocą wskaźników sprzyja redukcji tego fenomenu do wskaźników i zapoznaniu jego istoty. Czasem zbytni formalizm w traktowaniu standardów skłania do gromadzenia i prezentowania nadmiernej ilości danych i wskaźników maskujących faktyczną kondycję społecznej odpowiedzialności firmy, będących bronią przeciw biurokratycznym „nalotom dywanowym”23.

Istotna bariera $\mathrm{w}$ urzeczywistnianiu idei społecznej odpowiedzialności jest trudność weryfikacji i kontroli przestrzegania standardów CSR oraz brak sankcji za ich naruszenie, co dobrze ilustruje inicjatywa Global Compact. Partycypacja w tej inicjatywie wymaga wysłania listu intencyjnego do sekretarza generalnego ONZ, w którym dana organizacja deklaruje przestrzeganie 10 Zasad Global Compact w postaci działania na rzecz ochrony środowiska, praw człowieka, praw pracowniczych i przeciwdziałania korupcji. Osiagnięcia w obszarze tych działań i postęp w ich urzeczywistnianiu są prezentowane w sporządzanych przez firmy corocznych raportach, które powinny być przesyłane do centrali GC. Jednak raporty nie podlegaja żadnej weryfikacji, nie przewiduje się żadnych sankcji za naruszanie zasad, jedynym środkiem dyscyplinującym jest wykluczenie z inicjatywy tych firm, które nie sporządziły raportu. Nie są zatem zaskakujące wyniki badań Debby Bielak i in. wskazujące, że spośród 391 menedżerów wysokiego stopnia, którzy przystapili do inicjatywy Global Compact, tylko 27\% przyznało, że wprowadziło zawarte w niej zasady do praktyki zarzadzania ${ }^{24}$. Dla wielu firm logo Global Compact ma znaczenie głównie marketingowe i wizerunkowe, toteż informacji, że liczba członków

${ }^{23}$ J. Elkington, Trust Us: The 2002 Global Reporters Survey of Corporate Sustainability Reporting, SustainAbility, London 2002.

${ }^{24}$ D. Bielak, S. M. J. Bonini, J. M. Oppenheim, CEOs on strategy and social issues, „McKinsey Quarterly" 43, 2007, s. 8-12. 
Global Compact rośnie ${ }^{25}$, nie należy utożsamiać z rzeczywistym wzrostem społecznej odpowiedzialności biznesu.

Poważnym źródłem zawodności standardów CSR bywa erozja indywidualnej odpowiedzialności, czemu sprzyja kodyfikacja reguł tej odpowiedzialności ${ }^{26}$. Członkowie organizacji nastawieni na postępowanie zgodne $\mathrm{z}$ regułami zawartymi w kodeksie nie trudzą się etyczną refleksją i deliberacją ani nie są skłonni do podejmowania osobistej odpowiedzialności w niestandardowych sytuacjach. Na niebezpieczeństwo takiej postawy zwracali uwagę filozofowie, np. Ludwig Wittgenstein zauważał, że człowiek przestrzegający zasad, których nie wybrał, będzie przestrzegał ich ślepo ${ }^{27}$. Im większą wagę przywiązuje organizacja do zachowań zgodnych z ustalonymi wcześniej logicznymi schematami, w tym większym stopniu jej członkowie będą przywiązani do sztywnych procedur podejmowania decyzji, mniej dbajac o to, by były to słuszne decyzje. Troska o postępowanie zgodne z procedurami przesłoni dążenie do tego, by słusznie postępować. Verner C. Petersen zauważa, że kiedy jednostki starają się postępować według ustalonych schematów, w jakimś sensie traca panowanie nad swoim działaniem, nie jest ono czymś, za co czują się odpowiedzialne ${ }^{28}$. Literalne przywiązanie do zasad zapisanych $\mathrm{w}$ kodeksie etycznym może powodować „obsesyjne ich przestrzeganie” ${ }^{29}$ kosztem budowy relacji interpersonalnych i podejmowania decyzji zorientowanych na wartości. Zdarza się, że owe zasady zostają przejęte z zewnątrz i nie przystają do konkretnych warunków, co sprawia, że ich respektowanie jest kontrproduktywne ${ }^{30}$.

Znaczącym powodem niewysokiej efektywności standardów CSR jest szczególny tryb ich przyjmowania przez firmy. Zobowiązania społecznej odpowiedzialności są wprawdzie podejmowane dobrowolnie, ale owa dobrowolność jest wynikiem swoistej poprawności politycznej, przemożnego nacisku, któremu podporządkowuje się większość firm i zarządzających nimi menedżerów. Choć nie wypada wyłamać się z obowiązującego trendu nakazującego składać patetyczne i uroczyste deklaracje wobec społeczeństwa i środowiska, to można je traktować czysto ceremonialnie i w wielu przypadkach tak się właśnie dzieje. Zapisy znajdujace się w misji, kodeksie czy raporcie nie mają większego znaczenia dla codziennego funkcjonowania firmy, przyjmowane są wyłacznie z powodów wizerunkowych ${ }^{31}$.

Wielość i różnorodność standardów CSR sprawia, że w różnym stopniu pozwalają one urzeczywistniać idee społecznej odpowiedzialności. Porównując efektywność wybranych typów standardów w perspektywie neoinstytucjonal-

${ }^{25}$ Do inicjatywy Global Compact przystapiło ponad 13 tysięcy podmiotów (firm i organizacji pozabiznesowych) ze 170 krajów; zob. https://www.unglobalcompact.org/what-is-gc/participants [dostęp: 10.05.2017].

26 S. de Colle, A. Henriques, S. Sarasvathy, op. cit.

27 L. Wittgenstein, Dociekania filozoficzne, tłum. B. Wolniewicz, PWN, Warszawa 2012.

${ }_{28}$ V. C. Petersen, Beyond rules in society and business, Edward Elgar Publishing Limited, Cheltenham 2002.

29 S. de Colle, A. Henriques, S. Sarasvathy, op. cit.

${ }^{30}$ D. Seidl, Standard setting and following in corporate governance: an observation - theoretical study of the effectiveness of governance codes, „Organization” 14(5), 2007, s. 705-727.

${ }^{31}$ M. Behnam, T. L. MacLean, op. cit. 
nej, Michael Behnam i Tommy L. MacLean ${ }^{32}$ wskazali na kilka czynników, które ją warunkuja. Utrzymują oni, że standardy CSR są mocno włączone w praktykę działania firmy wtedy, gdy sa jasno zdefiniowane, koszt ich implementacji jest wysoki, ich przestrzeganie musi być udokumentowane oraz gdy przewidywane sa sankcje za ich naruszenie, natomiast odrywają się od tej praktyki wtedy, gdy wiążą się z niejednoznacznymi oczekiwaniami, nikłym kosztem implementacji, niedostatkiem kontroli i brakiem sankcji za nieprzestrzeganie wymagań.

Pomimo wszystkich zastrzeżeń, standaryzacja CSR jest niezbędnym warunkiem urzeczywistniania tej idei. Wiedza na poziomie ogólnym dotycząca ograniczeń standaryzacji i znajomość słabości poszczególnych standardów pozwala na wytyczenie zakresu nieoznaczoności i związanego z nimi ryzyka.

prof. dr hab. Anna Lewicka-Strzatecka

Instytut Filozofii i Socjologii Polskiej Akademii Nauk

Warszawa

alewicka@ifispan.waw.pl

DOES THE STANDARDISATION OF CSR CONDUCE TO RESPONSIBLE BUSINESS?

Sum mary

The aim of the paper is to disclose the limitations of Corporate Social Responsibility (CSR) standards. First, the aims and forms of CSR standardisation and the spectrum of CSR standards including their possible classifications are presented. The next part of the paper deals with the empirical data verifying the efficiency of CSR standards which often prove to be dysfunctional or even enhancing irresponsibility. The last part is devoted to the analysis of the causes of the unreliability of CSR standards.

\footnotetext{
32 Ibidem.
} 